\title{
A case study concerning the strategic plan: V2020 of Chosun University
}

\author{
Kiyoung Kim \\ College of Law, Chosun University, Gwang-ju, South Korea
}

Email address:

kiyoungkim@chosun.ac.kr

To cite this article:

Kiyoung Kim. A Case Study Concerning the Strategic Plan: V2020 of Chosun University. Science Journal of Business and Management. Vol. 1, No. 4, 2013, pp. 43-57. doi: 10.11648/j.sjbm.20130104.11

\begin{abstract}
This paper shows a typical of strategic planning process involving a local university in the transformative society as well as quasi-privatization drive from the government. Chosun University was chosen as an object of this case study, which faces a high demand of environment and challenges. A comprehensive process often undertaken in the strategic change process was applied to this institution, and shows how it initiated the process, conducted a stakeholders analysis, identified the strategic issues and strategies in the vision for 2020 (V2020). The article shows a paradigmatic application of strategic theory and process to the higher educational institutions, and also includes some of reflections on the strategic studies as a conclusion.
\end{abstract}

Keywords: Strategic Planning, Stakeholders Analysis, Strategic Issues, Adoption of Strategies, Implementation of Strategies, Monitoring and Reevaluation, Higher Educational Institution

\section{A Description of Organization}

Chosun University (hereinafter CU) is an organization for this final project. I chose them because I worked there as a professor since 2005. I began my teaching job as an associate professor of law, and the university launched a plan to prepare for the law school project. Afterwards, I have served a full-time professorship, and have taught the international, constitutional, and common laws. In 2010, I promoted as a professor and was guaranteed of tenured position. In this backdrop, the university is well known to me. Additionally, Gwang-ju, the local city in which CU is located, is my hometown where I lived until I was ten years old. Eight years of my service is not short that I could properly look into the nature of organization as well as the context of strategic planning process. This allowed me a more intimate research, and I believe that it offers an experimental subject for the organization studies. It generally has common traits as with other non-profit organizations, but there are some points of distinction. CU is a higher education facilities. It is a non-profit organization and has the goal about teaching and research. Their function is to educate the college students and produce a scholarly work to serve the public. CU is a private university, and keenly affiliated with the local community. An academic strength is modest, and the institution is large to have more than 900 instructors and professors. CU, located in the southern part of Korea, is a private institution, and regionally competes with Chon Nam University. $\mathrm{CU}$ is distinctive in that a school policy is liberal. This is proven that it has an independent Faculty Board (CUFB) interplaying with the university administration. CU members, i.e., students and faculty, would favor the social virtue and justice, and in some cases, they place those as higher than the academics. One often notes that CU was one of national heart for the student activism during 1980's. The times underwent a political turmoil. CU is housed in Gwang-ju, South Korea, the city of democratic sanctity. The management of CU is relatively stable, and the Board of Regent partly supports a financial need. As the situation goes tougher, the financial prospect became little pressuring. The size of student body and faculty, as well as educational performance has gradually increased in the national and regional context. However, the quasi-privatization initiative from the government and radical decline of youths generation posed serious challenges for the university administration (Hickman, G.R., 2010). 


\section{Organizational Mandates and Mission \& Values}

A context of foundational spirit espoused earlier in 1949 would create the basis on which CU in this new millennium now stands. A legacy and heritage to guide the professors, staffs, students and alumni have shaped the current form of local university, which has endured to interplay with $\mathrm{CU}$ for the development and adjustment with the change needs. A foundational spirit declared in the web page of $\mathrm{CU}$ clarifies the missions and goals that earlier CU should direct themselves (Bolon, D. S., 2005). The ethos and compassion to institute $\mathrm{CU}$ underlay the crux of national education implored to struggle with the Japanese emperor for its independence. They saw it only achievable by raising a competent and qualified caliber full of the national spirits. The Association of Founding Members revived in May, 1946, right after the national independence of Korea. It reprised its mission from the modern university movement frustrated by Japanese suppression during its imperial rule. The founding members range across the class of society, i.e., intelligenza, public officers, land owners, feudal subjects and local farmers. A qualification for the membership was completely open for a class of locality, and the number of members reached as many as 72,000 at the application for the governmental approval. The nature and quality of founding members in combination with their size obviously legitimate $\mathrm{CU}$ as pomp of local private university (2005).

This backdrop contributes to create a college and university morale, spirit, ethics, ethos, and dominant culture and passion as well as its organizational mission. We can derive several points of focus envisaged by these earlier educators, which, of course, influenced to found the current paradigm of university. An erection of independent nation, culture and intelligence was raised to serve the temper and needs of new nation. The concept of democracy, pragmatic and professional education gave rise to an expansion of university education for the prospective students (Lee, S. F., Lo, K. K., Leung, R. F., \& Ko, A. S. O., 2000). CU now pursues the organizational goals in three primacies. It continues to improve the educational facilities and environments, to upgrade for the quality education, and to foster the ethos of teaching and learning. This new initiative of university reform sparked around 1987 and 1988, in bitter reflection of stalemate and resilience, as deviated from such dynamic and vibrant vision of foundational agreement. The initiative was supported by the members of $\mathrm{CU}$ and local community. It accomplished a more perfect system of campus democracy and efficiency in the university administration, and became one of role models for the private universities in Korea. This remarked success inspired a subsequent generation of campus community, and still in continuance within CU.

The mission statement of CU has pronounced three items in most primacy, which was ultimated in a slogan form of sentence for effective communication and clarity of message (Bolon D.S., 2005). Let me present literally in translation from the web page of $\mathrm{CU}$, "CU shall educate the competent and knowledgeable students who can contribute to the welfare of nation and common prosperity of world; To serve this mission, it purports to breed a creative mind of student well qualified for this globalized society. Second, it fosters a caliber of professionals networked with the industry and competent to develop the nation and society. It focuses on the deprived, but prospective and well-prepared students by boosting the financial assistance system. CU, in the pursuit of its mission, framed four sectors of strategic goal as announced in its web page publicly available (2005). They include the elements of "creativity, technology, public service and globalized context of intelligence and knowledge." The ultimate goals of CU, in line with that of national educational goals and spirit of founding members, is to educate a professionally competent graduate who contribute to the nation and global village by in-depth knowledge, wisdom and innovation, teaching and public service (Lee, S. F. et al., 2000). In this end, it provides an individualized paradigm of education breeding their creative students (McVea, J. F., \& Freeman, R. E., 2005). It endeavors to educate technologically competent students to pioneer the information society. It facilitates fostering the social leaders, who are devoted and enthusiastic to serve the nation and community. $\mathrm{CU}$ also is committed to produce a quality of professionals with the international competence and requisite knowledge. In the campus leadership since 2012, CU has more clearly envisioned the direction and goals to meet the challenges from a high speed transformation in the society. Chancellor Seo visualized three strategic points of focus in terms of the global brand value, competitive characteristics on the integration and concillience, transformational leadership and university reform (Free Management Library, 2013b). In his vision of leadership, CU would upgrade from the 15 th rank of nation toward the global brand of university. For this strategic initiative, it promotes a global profile of university and facilitates the international programs as well as interchange with the world class universities. This brand value university requires a democratic governance and culture within the campus as well as transparency of university administration (Bolon, D.S., 2005). It enables the "diversity of campus, democratic training, common respect and socialization."

A vision we pursue to meet the challenges of future is related with the nature of social transformation (Bryson, J.M., 2011). The future of society will underlie the era of human ethos and artistic concepts as well as the high extent of integrative paradigm. This prospect of social transformation requires an innovation of 21 th education as consumer-suited, who are competent and qualified, and creative to pioneer a new frontier of knowledge by integrating the arts, humanities and social or natural sciences. This new perspective and vision will foreground 
the pathways of CU (Bolon, D.S., 2005). For the last, the new campus leadership stresses a square aspect of reform and innovation in order to meet the challenges and to overcome a crisis. In the authentic commitment to the role of public education in this society, $\mathrm{CU}$ will launch a new strategic change process to resolve the urgent issues, .i.e., system building with the local industries for the development of local economy, innovation in education as well as procurement and improvement of the infrastructure, as well as the quality student services. The vision and goals will eventually realize a local and national prestige as ranked 15th, and CU also will improve as the center of east Asian universities and toward an internationally renowned university (Burke, W.W., 2010).

\section{An Identification of the Stakeholders and their Level of Support}

By utilizing the "Power v. Interest" and "Power v. Support" grids, I identified a several of key stakeholder groups concerning the VISION 2020 (hereinafter V2020). The scope of key stakeholders listed below is never exhaustive, but selective to explain a major profile on the ground of power, interest, and their position about the plan (Parent, M. M., \& Deephouse, D. L., 2007).

- Students of CU (A1)

- Professors and Lecturers (A2)

- CU Chancellor and Key Officers (A3)

- $\quad$ The Gwang-ju Community (A4)

- Chosun University (A5)

- Other National Universities (A6)

- Chon Nam National University (A8)

- National and Local Government (A10)

- $\quad$ Parents of CU and High School students (A11)

Let me briefly explain the reasons to choose for some of major groups, and the logic or rationale may well apply to the rest of others.

Students of CU share a keen interest in the success of V2020. They are actually a client for the CU educational business, and expect a high quality of teaching and education, which would equip them with the requisite knowledge to survive a social or professional demand (Dewhurst, S., \& FitzPatrick, L., 2005). They also have an interest about the increase of tuition fee, and the financial plan of $\mathrm{CU}$ would be concerned with their perception or evaluation of V2020. They are actually less powerful since their voice and share of influence in the strategic planning process is minimal or merely participatory. However, they officially are ensured to represent their view and opinions by pronouncing their policy position in the name of $\mathrm{CU}$ Student Association. They also are statutorily provided a limited share of voting right in the election of university chancellor. They generally support a restructuring plan since it purports to increase the quality education and competitiveness (2005). However, we can identify selective cases of antipathy or opposition if the merger and acquisition (hereinafter M\&A) of departments unexpectedly harms the currently enrolled students. A notable example would be found in the Global Law whose students are academically superb than the general law students, but the department now is planned to be removed in three years monitoring period. They highly disfavor to graduate as a general law degree which is, however, highly probable for the first year Global Laws.

Merged faculty members and lecturers dominantly take a side as the opposing party since the administration intends to touch on the sensitive academic issues concerning a departmental M\&A and abolition. A restructuring and downsizing initiative are inimical to their sense of pride and life-time apprehension about the status and personal direction. They often hold a social esteem as a university professor and tend to exhibit a dislike if their professional pride is to be attacked. Therefore, their interests would be mostly strongest among other stakeholders, and the divide between "support and opposition" would be seriously stark. Their power should also be rated generally higher since they actually are key players in the colleges and universities. As the strategic change was initiated, a confrontation or concession between the Faculty Board and university administration would come obvious. Their power perhaps would be balanced. It is a central issue how to cultivate them into the deep and genuine motivation to engineer V2020 (2005).

CU Chancellor and other key officers would be placed mostly higher than any other stakeholder across all the three factors, i.e., power, interest, and support. They are actually an official authority to initiate, process and approve the strategic plan except for a formality of board approval. A current chancellor has had hard times since he was unreasonably rejected of his appointment by the board in 2010. His debut is, therefore, dramatic upon the democratic alteration of board rejection and reelection in 2011. He is 62 years old that the term of chancellor would make him to retire upon its termination. Therefore, his compassion would be stronger to develop $\mathrm{CU}$, and he will likely perform his leadership role in concession and harmony with the Faculty Board. Hence, his interest to develop CU and interact more vigorously with the faculty members should be highest among the key stakeholders. Key officers dominantly are composed of his loyal followers in the previous election, and generally could be placed at the same nature.

Gwang-ju community should be included since $\mathrm{CU}$ has long interacted and actually been fostered by their concern and involvement (2005). Generally it would less directly be affected by the heat of plan. However, V2020 stems from the environmental change of youths generation decline, which is strongly affiliated with it. They would be classed as subjects provided that they possess a high interest in the strategic plan, but the power to influence is indirect or weaker (Gousseau, K., 2008). They like to find CU would attain a national and regional reputation, one factor of their pride and community morale. They are also interested since 
they are parents and employers. They generally are supporters to boost the development of CU (2008). This analysis would apply to other stakeholders in the same manner as identified below (Free Management Library, 2013a).

Let me capture various stakeholders listed above by way of two helpful diagrams from the resources of class material (Bryson, J.M., 2011).

\section{(1) Power V. Interest Grid}

- $\quad$ Players : A2, A3, A5, A6

- Context Setters : A10, A12

- $\quad$ Subjects : A1, A5, A8, A11

- $\quad$ Crowd : A4, A7

\section{(2) Problem-Frame Stakeholder Map}

- $\quad$ Strong Supporters: A2, A3, A5, A6

- $\quad$ Strong Opponents: A7,

- Weak Supporters: A1, A4, A6, A9, A11

- Weak Opponents: A8

- $\quad$ Strong Neutrals: A10, A12

\section{A Demand from the Environment and Strategic Issues}

In order to upgrade $\mathrm{CU}$ as nationally renowned university, the strategic plan, titled V2020, identified four sectors of strategic issues, which covers a "finance and treasury, education, research, and university administration" (Strategic Plan for the Department of Auditor-Controller of the County of Los Angeles, 2013). In a work to identify the organization's strategic issues, Bryson introduced basic eight ways in use of organizational practice, which, among others, are the direct approach, goals approach, system approach, and action-oriented research (2011). I believe that these four would fit within the context of CU plan. An indirect approach would have a little relevance in V2020 given that the challenges and change demand are a nationwide flux for the public universities enduring this decade. The members of organization often have a high awareness of the strategic need of restructuring, and actually are highly concerned of the mission, vision statement, goals and issues (Laureate Education Inc., 2013b). They know the success of plan is vital to survive the unprecedented crisis that many universities, including CU now face (2013b). For its nature of fundamental shift in paradigm, the alignment thesis, often detailed on comparison with the gaps, inconsistencies, and conflicts, seems less proper, which perhaps would focus on some incremental nature of change (Bryson, J.M., 2011). With this process of selection, I found the ways in complementary approach, the focus of which is placed on the direct approach. The direct approach is one of most popular ways, and particularly useful of governments or nonprofit organizations since their mission and vision or goals are generally common, stable, well defined and readily or expressly identifiable (2011). This aspect can be shared by $\mathrm{CU}$ provided if it has a clear set of written mission and vision statement, and their social responsibility is readily defined in terms of quality education and research. The goals approach takes a share to identify and describe the strategic issues since it guides and helps to clarify the issues with a logic and persuasion (2011). This traditional planning theory, therefore, creates the concern of stakeholders, and cultivates them into an advocate by developing their buy-in and commitment. The system approach also takes a part if the university system is generally common and predominantly systemized with the education, research, and finance and administration (2011). V2020 sectors of strategic issues precisely address these cores of university system. I also rely on the action-oriented approach in describing the strategic issues and strategies to address them although I do waive the diagram or arrows to visualize, yet to just narrate.

Three strategic issues can be identified from the mandates, mission, as well as the result of SWOT analysis as described later (Free Management Library, 2013a). In connection with these factors, it is required to look into a change demand from the environment. This should certainly be opportunities and threats for CU, who faces the challenges from a social transformation.

\section{The SWOT Analysis of V2020}

\subsection{Two Aspects of External Factors}

We can illustrate three basic problems CU now faces. As follows, you also can see the chart showing the statistics of youths generation decline. 


\section{Environment \& Challenge}
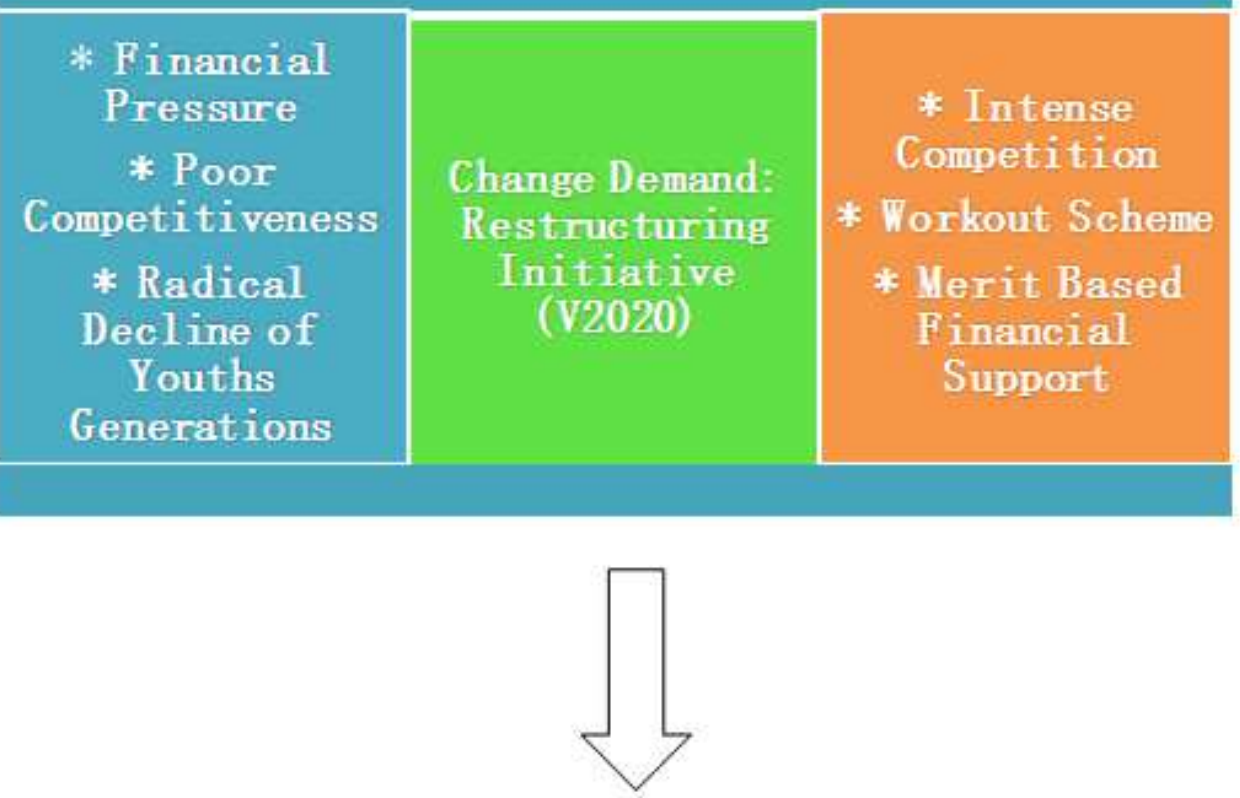

\section{Finacial Competitiveness}

\section{Educational Competitiveness}

\section{Research Competitiveness}

Figure 1. Problem Chart.

- Decline of Competitiveness and Productivity

- Decline of Youths Generations

- $\quad$ Pressure and Restraint from the Finance and Budget

Table 1. Youths Generation and Number of Applicants/Acceptance Rate.

\begin{tabular}{|c|c|c|c|c|c|c|c|c|c|c|c|c|}
\hline \multirow[t]{2}{*}{ Year } & \multirow{2}{*}{$\begin{array}{l}\text { Y.Gen.(18 } \\
\text { years old) }\end{array}$} & \multirow{2}{*}{$\begin{array}{l}\text { Local High } \\
\text { School } \\
\text { Graduates }\end{array}$} & \multicolumn{2}{|c|}{ Seoul Area } & $\mathrm{C}=(\mathbf{A}-\mathbf{B})$ & \multicolumn{2}{|c|}{$\begin{array}{l}\text { Chon Nam } \\
\text { Univ.(D) }\end{array}$} & \multicolumn{2}{|l|}{$E=C-D$} & $\begin{array}{l}\text { Other } \\
\text { Area } \\
\text { (F) }\end{array}$ & \multicolumn{2}{|l|}{$\mathbf{H}=\mathbf{E}-\mathbf{F}-\mathbf{G}$} \\
\hline & & & $\begin{array}{l}\text { Move } \\
\text { (no.) }\end{array}$ & $\begin{array}{l}\text { M. } \\
\text { Ratio }\end{array}$ & Room 1 & Quota & $\begin{array}{l}\text { M. } \\
\text { ratio }\end{array}$ & Room 2 & & Room 3 & $\begin{array}{l}\text { No. } \\
\text { Appl. }\end{array}$ & $\begin{array}{l}\text { Accept. } \\
\text { Rate }\end{array}$ \\
\hline 2012 & 48,344 & 465,76 & 5,611 & $12 \%$ & 41,152 & 3,460 & $7 \%$ & 37,692 & $81 \%$ & 1403 & 17,736 & 3.7 \\
\hline 2020 & 35,659 & 34,523 & 5,611 & $13 \%$ & 28,912 & 3,460 & $10 \%$ & 25,452 & $74 \%$ & 1036 & 10,719 & 2.2 \\
\hline 2030 & 25,978 & 25,128 & 5,611 & $22 \%$ & 19,517 & 3,460 & $14 \%$ & 16,057 & $64 \%$ & 754 & 5,333 & 1.1 \\
\hline
\end{tabular}


The opportunities of CU can be in three folds. First, the globalization and development of information technology are geared toward the intensity of nation and local community, as well as the extension of oversea interchange. They diversify or develop a scope of campus activities and performance. Other opportunity is laid in the increased network and collaborative nature of local community (Laureate Education Inc., 2013b). National development strategies often stressed by the government focused on the local core for alleviation of the problems arising from the dense populace and clustered industries of Seoul, as well as for the fair opportunity and balanced development between the capital and major national localities. Third, the government launched a quasi-privatization initiative for rationalization and selective investment. This point can be either an opportunity or threat (Sherman, H., Rowley, D. J., \& Armandi, B. R., 2007). Provided if CU successfully penetrates the change process, the survival is certainly likely to ensure the entering of nationally ranked universities. The strategic cycle period from 2013 through 2020 should be testamentary and of intense contest between a greater leap and closure down. The paradigm of governance and statecraft concerning the national policies now transforms toward small but competitive model of northern European nations, such as Sweden and Holland. The government requires a competitiveness to companion with the holistic progress of nation, but with the social welfare framework on a grant or assistance. This is challenging, but also offers an opportunity for the modest nature of local university.

\subsection{Two Aspects of Internal Factors}

For the next step of internal assessment, we are required to investigate the strengths and weakness (Bryson, J.M., 2011). In the first, we can properly draw upon its tradition, legacy, compassion, and high support of local community. One commentator predicts eloquently, "CU is a living legacy for the democracy and nationalism of Korea." Others also agree that CU is deeply rooted on and has had an embedded relationship with the concerned group and intellectuals. On this ground, it would not easily collapse from any serious challenges or threats. Other point of strengths is the participatory leadership, and democratic process of decision making. CU leaders have been chosen from the campus ballot except for few cases in earlier years. Thus the leadership often would be effective to mobilize the change process from the workforce of faculty members and staffs, and students' support. This context of internal process implies that the strategic plan, once agreed on the wider basis of campus community, would find virtually no obstacles to implement through its success Sherman, H. et al., 2007). Finally, CU has the strength of personnel and physical resources, and operates within a well- designed work flow and administrative system (Kaufman, R. et al, 2003). Its campus is considered second to none in its beauty and fine scenery. Rose Garden is most popular place that local people entertain in the weekend and holidays. There are historic sites in the campus, and many tourists nationwide visit a vicinity and even campus. The staffs and administrative team often are composed of experienced servers and alumni of CU. Their loyalty and competence seem to operate in effecting the strategic goals of V2020. The work branches and units have been organized to produce most effective outcomes across the main administration, academic departments, and other centers or institutes. It exposes an art of efficient management stream for collaboration, cooperation, and coordination (2003).

In contrast, we are able to identify three points of weaknesses that the present $\mathrm{CU}$ should problematize to address. First, the nature and quality of faculty members are largely resilient and negative against a drastic change and less supportive of business concept concerning the campus strategic plan. A conservative ethos and high adherence on the democratic process generally militate against the strategic restructuring and change initiative. Second, a weakness comes from the Board of CU, which has been chronicled over the past thirty years. The Board of $\mathrm{CU}$ is a final authority to decide the university issues, controversies and key agendas. . Earlier since 1981, the board members of $\mathrm{CU}$ have been appointed by the government on the statutory ground. Therefore, its nature actually is temporary and organized in the requirement for corresponding to the emergency of university. This anomaly, in contrast with other universities, has contributed to the turmoil and dissention among the organizational members. The campus vigor and harmony had been abridged, and this context of controversial CU Board is sheerly a weakness to vitiate the strategic planning. Third, the southern culture of Korea is often procrastinating, less proactive, settled and emotional. This could be a strong attitude in some aspect, but largely militates against an organized, scientific collaboration and systemic cooperation (Laureate Education, Inc., 2013a). The members would more readily rely on the faces and names, sensibility or communal compassion other than logic, goals, legitimacy, or standard and regulation. As V2020 would realize into a concrete university regulation, this aspect should have to improve in ensuring the effective implementation, monitoring and reevaluation (Kaufman, R. et al, 2003).

The present status of $\mathrm{CU}$ as above depicted leads to the following three consequences (Free Management Library, 2013c). First, the colleges and universities in Korea now are compelled to compete and struggle for a survival. The Government launched a phase of nation- wide restructuring concerning the college and university education. They regularly conduct an investigation and assessment about the quality, utility, financial credibility and soundness, as well as resources. This engagement penetrates a square of university factors, which later is reported to the public in the form of credit roll. Some universities are ranked less credible, or deprived class, and other universities actually 
are adjudged a work out. Given the high extent of financial dependency, the universities of Korea, which are disqualified of the eligibility to be funded or financially aided, would find no ways to discontinue. The classification of universities in terms of different financial status can well be translated into the kind of vital pressure toward a strategic change or restructuring. In this background, we can present three strategic issues by three sentences of self-inquiry (2013c).

- To what extent and how do we increase the financial and budgetary competitiveness?

- To what extent and how do we upgrade the educational competitiveness?

- To what extent and how do we raise the competitiveness of research?

\section{Several of Major Strategies in V2020}

In order to increase the quality education and innovative minds, CU needs to opt for an M\&A of several departments which are considered as less competitive. The standard of selection will be adjudged based on the similarity of disciplines and level of competitiveness. More similar and less competitive it would be, more probable it would be merged. The M\&A strategy can be understood to grow a competitiveness and departmental vitality. Some departments will be closed down or the legal quota may reduce. The strategy also serves an intensification and upgrading of liberal as well as professional education because a redundancy of subjects or courses can be removed to survive one effective department (Roth, B. N., \& Washburn, S. A., 1999). In other point, it can serve to facilitate a networked development from an undergraduate through the graduate education (Fogg, C.D, 2012). M\&A issues are actually controversial to involve the interest of departments seriously, and thus the strategies to enforce will be based on the following principles. First, a voluntary adjustment will have a firsthand favor through a consultation and consensus among the concerned departments. A special status of departments classed on the competitiveness ground would be given a priority in the process. Over 40 percents of redundancy in subjects within the discipline would fall in the class of M\&A departments. Concerning the reduction of legal quota, the following principles will apply. It is compulsory to reduce a quota by ten percents provided that the assessment resulting from the past three years of statistics indicates the lower 20 percents within a cohort of similar disciplines. However, a smallsize department below 30 students in 2013, and the departments classed for a M\&A or status change will be exempted.

The M\&A strategy will progress with four occasions of public forum for an information, debate and exchange of ideas among the members and stakeholders (Aguilar, O., 2003). The first conference will be held at Dam-yang Hotel , Jan 9, 2013 (17:00-20:00). The participants will be limited to the key players who are a CU Chancellor, Directors of campus administration, and Deans of colleges. The second forum will be held in the university administration building, Jan. 15 (11: 30-14:00). The participants are a chair and members of CUFB, who are considered to represent the voice of faculty members and generally operate as a critique. The third forum will be held at Dam-yang hotel, Jan. $17^{\text {th }} \quad(14: 00-17: 00)$. The participants are a CU Chancellor and ranks of staff above the Team Directors. The fourth forum will be held at Seoseok Hall, Jan. 23 ${ }^{\text {rd }}$ (11:00-13:00). The participants include all scope of university staffs. This process to inform and mobilize the followership constitutes a crucial part of strategies, and will shrewdly be arranged to address the strategic needs (2003). It flows as cascade from the key strategic planning team, and the second meeting would be important to debate or repose to reach the consensus and agreement. The faculty members are key stakeholders in this issue, and collaboration and cooperation as well as coordination are highly relevant with the success of M\&As (Fogg, C.D, 2012). Not unexpectedly, however, a critical reaction and opposing movement have dominated the campus environment in this spring. Therefore, the repose period of time is critical to assemble the views and opinions from the members or stakeholders which would be set forth during Jan. 10-30. Besides this, a grassroots work in order to mobilize and seek the agreement of members are pivotal that the meetings and advising sessions are arranged to target at each college and department (2012). This period will span lengthier with two months series of meetings. Finally, the key players will gather six times to draft a final form of strategic plan on the M\&A of departments.

In responding to three strategic issues, $\mathrm{CU}$ developed a sector-focused growth strategy for merits and competitiveness (Roth, B. N., \& Washburn, S. A., 1999). This sectorization strategy will reduce a redundancy and low competitiveness, and can transform the university into a more effective form to address the needs of local community. This policy also can enhance the role of university to educate the creative minds and competent graduates. The weaknesses identified in the previous period would lie in: (i) the low rate of research performance; (ii) lack of feedback and monitoring system for the project units, management of research expenditure and research outcome; (iii) continued financial pressure for the university notwithstanding short-term foibles; (iv) deficiency of full support and lack of penalty system to ensure the accountability of project units (Rothaemel, F., 2012).

The sectorization strategy will be delivered to realize these three basic goals. CU will generate the energy and passion to increase the competitiveness of university by focusing on the competitive sectors most intensively (Aguilar, O., 2003). It implements a strategy in understanding that the strategy is essentially related with the increase of brand power and foregrounds the intake strategy of qualified students. The sectorization strategy 
will be pursued in understanding that it foregrounds and facilitates a voluntary reform of disciplines or departments and mode of education.

The sector-focused strategy already has phased and will progress over the time sequence with a varying class of colleges and departments (Roth, B. N., \& Washburn, S. A., 1999). In JUMP 2005, the information and communication, biotechnology, industrial design, electric engineering, and international cooperation were designated for the focal sectors. In NEW JUMP 2010, a competitive-edge material science, culture and information, biotechnology, energy and environmental studies, international cooperation were listed in the roll of focal sectors. In Happy Univ. 2015 and V2020, the media and cultural contents, U-health and silver industries, bio-materials and medicine, energy and environmental studies, and frontier machineries were enrolled. In pursuit of this strategy, CU will provide a support for three years during 2013-2015. The support will cover a financial aid as equivalent of $10 \%$ to the project dollars and administrative assistance, seed money to prepare for the application, working space, and manpower, as intended for the successful biddings in the national competition. The strategy will continue to formulate the sectorization strategic team whose members include key of twelve staffs (Fogg, C.D, 2012). Their role and responsibility are to select the project units and evaluation, as well as to prepare for the detailed support plans.

The third strategy to address a strategic change in V2020 will concern the aspect of financial administration. For a radical decline of youths generation in the near future will jeopardize to satisfy the legal quota of admits, hence, can well bring a foreseeable risk of management, finance and budget. This threat can be alleviated most primarily by upgrading the quality of education and brand power of CU. The sectorization and research initiative can serve a basic role and would be a cornerstone to bridge the producer (CU) and consumers (applicants). However, the conservative or saving-driven management strategy plays a secondary role to bring an administrative efficiency, and one way to tolerate the financial pressure. CU, in V2020, will endeavor to reduce the overhead and operational expenses. The scope of expenditure will target around a compensation of workers, fees and expenses, operational cost, incentive money and remuneration of the expenses for an employment brokerage, and asset acquisition taxes. The conservative management strategy also requires of an effective use of the space and facilities. Other point of strategy can be illustrated about the fair allocation of resources among many competing units and branches, for example, language institute, life-time learning center, university plaza, special graduate schools, and liberal education department (2012). In terms of efficient administration, CU will develop a new paradigm for the independence of budget and accountancy on a departmental basis, consumer-specific service and support system, as well as new initiative for the administration specialist education (Kotlin, A. D., 2008).

\section{The Implementation of Strategies and Monitoring}

Most important in the implementation of strategies would be the M\&A process to concern the departments strategically critical. The restructuring plan will be implemented on two phases for the initiative and focus during 2013, and follow-up phase through post-2013 years. In the initiative and focus, the shape of basic transformation will be determined and implemented several years through (Aguilar, O., 2003). This stage is expected to see an intense conflict and tension among the stakeholders, particularly from the faculty of merged or worse conditioned departments. As stated, the process design was carefully arranged to identify the strategic issues. A channel or forum to discuss was ensured for an effective communication and mutual agreement through the followers and leadership (Fogg, C.D, 2012). A retreat and follow-up meetings were scheduled for an authentic commitment, trust, prudence and consideration. The criteria for a M\&A are provided in the clear and agreeable fashion to minimize the troubles, misunderstanding and controversies. A redundancy of taught subjects and competitiveness of department are two key elements to assess. On these elements, the departments will merge among another if the extent of similarities and redundancy are found beyond 40 percents. A voluntary merger also is implemented through the inter-departmental negotiation and concession. Other aspect of implementation triggers a reduction of student quota compulsorily by ten percents on the condition that the department performs the worst of 20 percents within each group of assorted disciplines. In the post-2013 phase, the initial implementation would be updated and assessed in continuance through the end of planning period. The Competitiveness Assessment Team will annually report its findings for the campus leadership (Aguilar, O., 2003). This offers the basis to reassign the student quota. In principle, the upper 20 percents class in the competitiveness review is allowed to increase their student quota, and the lower 10 percents are mandatory to reduce by ten percents. In the worst cases, the department will be abolished when it performs the lower ten percents two times. Through the implementation phase, two pillars should be constant, i.e., the standing system to readily evaluate and assess as well as codification of criteria on the merger and reduction of student quota (Fogg, C.D, 2012). This aspect of implantation as well as corresponding elements on the monitoring and evaluation was charted in the following diagrams. 


\section{Inter-departmental Restructuring Plan}
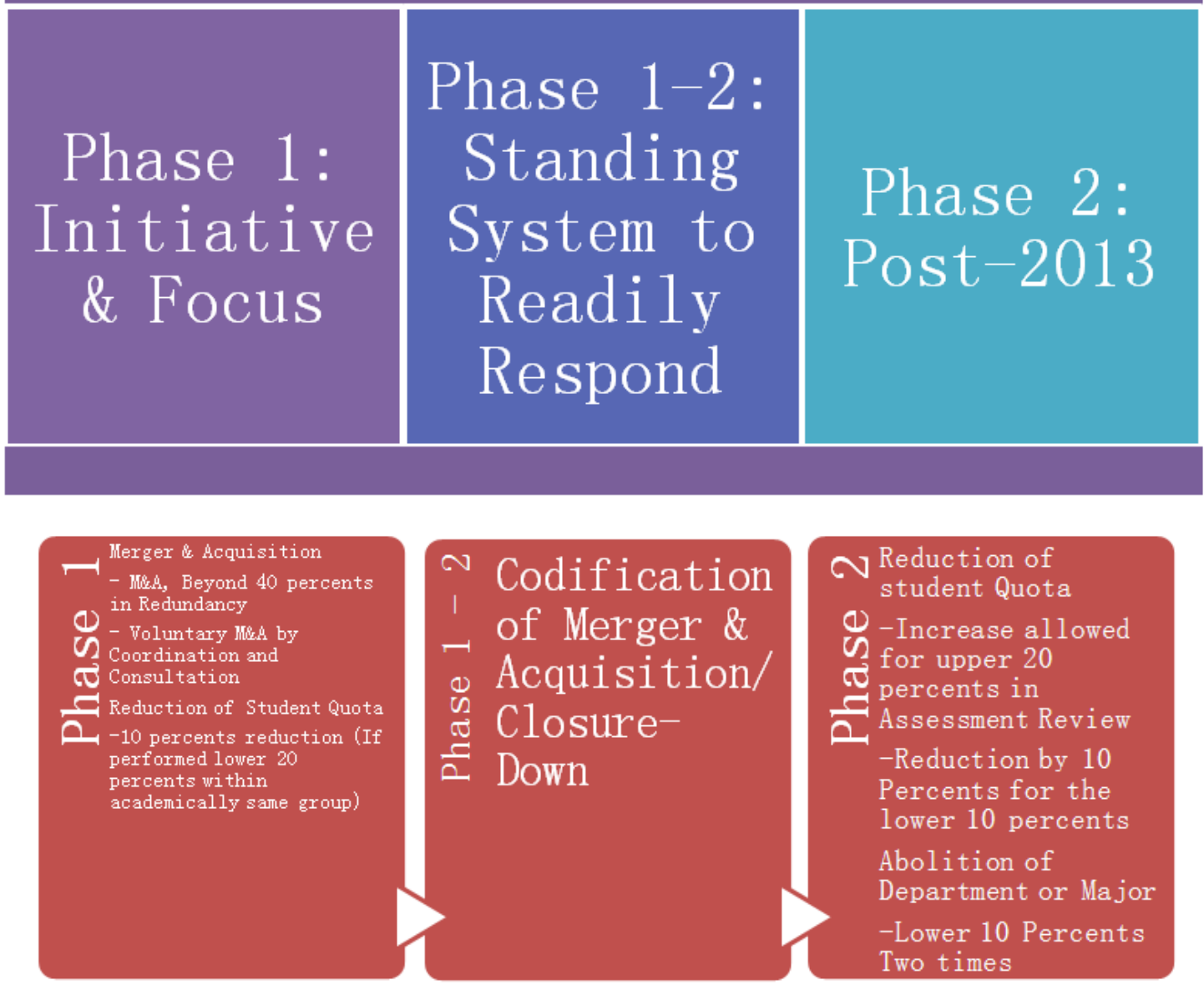

Figure 2. Implementation and Monitoring V2020

Table 2. Assessment Policy

\begin{tabular}{lcl}
\hline & QUANTATIVE INDICE TO SHOW THE PERFORMANCE OF DEPARTMENT \\
CRITERIA/ASSESSMENT & DATA FROM PUBLIC DISCLOSURE REQUIREMENT/EDUCATION COST \& RESEARCH \\
REVIEW & OUTPUT FROM INTERNAL RECORD \\
& INDICE COMPOSITE AND GRADE POINT (BASED ON THE CHARACTERISTIC OF \\
LOCAL PRIVATE UNIVERSITY \\
\hline
\end{tabular}

(1) EDUCATION COST (20\%) : RATIO FROM TOTAL EDUCATION COST / TUITION EARNINGS

- $\quad$ Bursar Account : (Faculty Salary + Operation cost + Research \& Student Expense) - \{Income Related Expense + Other Expense Unrelated with Education Cost (Interest Payment/Miscellaneous\}

- Excluded From Education Cost

- Income Related Expense

- $\quad$ Financial Support In International Programs

- $\quad$ Accrued From Campus-Industry Project
- $\quad$ Other Unrelated Expense

- Apportionment Method

- Direct Apportionment : Faculty Salary, Departmental Operation Cost, Attrition Cost For Exclusive Use Space, Departmental Staff Salary

- Method on Faculty Salary : (i) Education Cost Per Class $=($ Salary $\mathrm{x}$ Class Hours $) /$ Total Class Hours (ii) Departmental Cost $=$ Per Class Education Cost $\mathrm{x}$ (Total Audience For Department/Audience For Each Class)

- Indirect Education Cost : Staffs Salary for Main 
Administration and Institutes, Operation Cost of Administrative Branches and Units, Attrition Cost for Shared Space

Table 3. Grade Scale Table for Education Cost

\begin{tabular}{l|ll}
\hline Top Grades & Below 80 & 80 Points \\
Upper Grades & $80.1-90$ & 75 Points \\
& $90.1-100$ & 70 Points \\
Median Grades & $100.1-105$ & 65 Points \\
& $105.1-110$ & 60 Points \\
Lower Grades & $110.1-115$ & 55 Points \\
\hline
\end{tabular}

(2) ENROLLMENT RATIO OF STUDENT (30\%) : ENROLLED STUDENTS/STUDENT QUOTA $x$ 100

(3) EMPLOYMENT RATE (30\%) : INFORMATION FROM HEALTH INSURANCE DATA BASE AVAILABEL FROM PUBLIC DISCLOSURE RECORD

- Employment Rate on the Data Base of National Health Insurance

- $\quad$ Employed/\{Graduates-(Graduate School + Military + Disabled + Outside Insurance Policy + Study Abroad) $\}$ x 100

(4) RESEARCH OUTPUT (20\%) : PER CAPITA RESEARCH PERFORMANCE POINT FROM THE CAMPUS RECORD

- $\quad$ Number of Full Time Faculty (a)

- Total Research Performance Point (b)

- $\quad$ Per Capita Research Performance Point (b/a)

\section{The Organizational Future Vision: V2020}

The vision statement of $\mathrm{CU}$ has to be concise and conveys a message in any express and readily acceptable forms of expression. That should touch on the focal point of desired goals to implant clearly a visualized receipt to the audience. It should be explored in consideration of most effective ways to communicate the ideas and meanings to the addressee. The vision statement can operate as a point of reference and created the followership essential for the organizational change or restructuring (Millett, S. M., 2006). The vision statement often includes a definite terms of quantity or clear message of qualitative nature, and often gets better with a higher transparency. It would be a yardstick to measure the skills and sagacity of strategic planners, and representative part of whole strategic plan (2006). V2020 would include the following vision statement: "CU would relentlessly pursue an innovation and reform to continuously implement the five core of vantage points as well as to achieve ten goals in focus and priority. CU, in the commitment to build-up of trust, harmony, unity and innovation, will head forward through the maximum happiness of university family. CU will enter around a $15^{\text {th }}$ rank among the national universities by $2020 . "$

This vision will be enabled by mounting on the five core of vantage points (Zollo, M., Reuer, J. J., \& Singh, H., 2002). First, CU will ensure the soundness of finance and budget by the innovative strategic management. To this end, the university income will diversify its source from the traditional high dependency on tuition that the ratio of tuition will be reduced to half of total (ranked $30^{\text {th }}$ among the national universities). Second, CU will breed a creative social elite, and focus its time and energy on the improvement of employment rate. The employment rate at the time of graduation will rise up to 70 percents (ranked $\left.10^{\text {th }}\right)$. Third, CU will keep pace with the global concept of higher education, which promotes the intake of oversea students and invigorates the international exchange programs. The ratio of foreign students enrolled in the degree program will grow for $4.5 \%$ (ranked $20^{\text {th }}$ ). Fourth, CU will strengthen the campus-industry network and cooperation by means of the flourished research. The research project funded by the exterior institutions will increase at $1.2\left(\right.$ ranked $15^{\text {th }}$ ). Fifth, CU will direct its ways for the maximum of quality life and their happiness. A national reputation ranking would improve at 35\% (ranked $\left.15^{\text {th }}\right)$.

For the accomplishment of five vantage points, CU will continue intensifying on ten strategic goals (2002). It innovates for the efficient administration and creates a forprofit business or enterprise. CU will restructure several academic departments by the M\&A and improves the quality and competence of students. It also intensifies a support to boost the start-up companies. CU will promote the In-English class of major subjects, and make an efforts to hire a foreign professor. It also encourages the international exchange programs for the students. By providing an incentive system, $\mathrm{CU}$ will encourage the campus researchers to be a most beneficiary of national projects. CU will strengthen the network and cooperative ties with the fields of industry. CU will introduce a departmental concept of budget and audit as well as prioritize the increase of donations.

\section{The Plan Adoption of V2020}

V2020 has undergone through the phases of planning process, beginning with the mission and vision statement, stakeholders' and SWOT analysis, identification of strategic issues and strategies to address them. Now the plan needs to be placed to seek an official adoption. According to Bryson (2011), the plan adoption actually is the culmination of strategist work as coupled with the vision summaries. The documentary form of strategic plan and vision summaries ideologically and practically represents the desired place where the organization intends to reach (2011). It shows major points that the leaders and followers should make a strenuous effort to implement, feedback and monitor, and recycle or revise the strategic 
process. We can find three basics to factor in the plan adoption, which would be "problems, solutions, and politics." While the first two largely remains in the expertise and technicality of planners, the politics would be the point that each organization or the context of planning process can well diverge to successfully penetrate through the official adoption. The first two may merge if the nature of planning process allows, notably, for the small scale plans. On the other, the hard nature of legislative approval may fail the adoption, and the kind of plan under the firm commitment or auspice of powerful players, as in case of private firms and CEOs, may have much more chances for approval (2011). This aspect of politics in V2020 actually has been serious over the months since the plan includes a loss or injuries for the merged departments. Therefore, the plan was pushed carefully to persuade the aggrieved professors and staffs, as well as pursued in open context of free debate or mobilization of firm agreement. Overcoming the controversies and complaints from several groups, the plan had been finally adopted by the Chancellor with the advice of the Commission of Academic Affairs (CAA), and soon after, the Board of CU approved the plan in this May. Let me brief the final form of strategic plan and create the vision for the future. The use of diagram can facilitate a more effective communication with the leadership and followers.
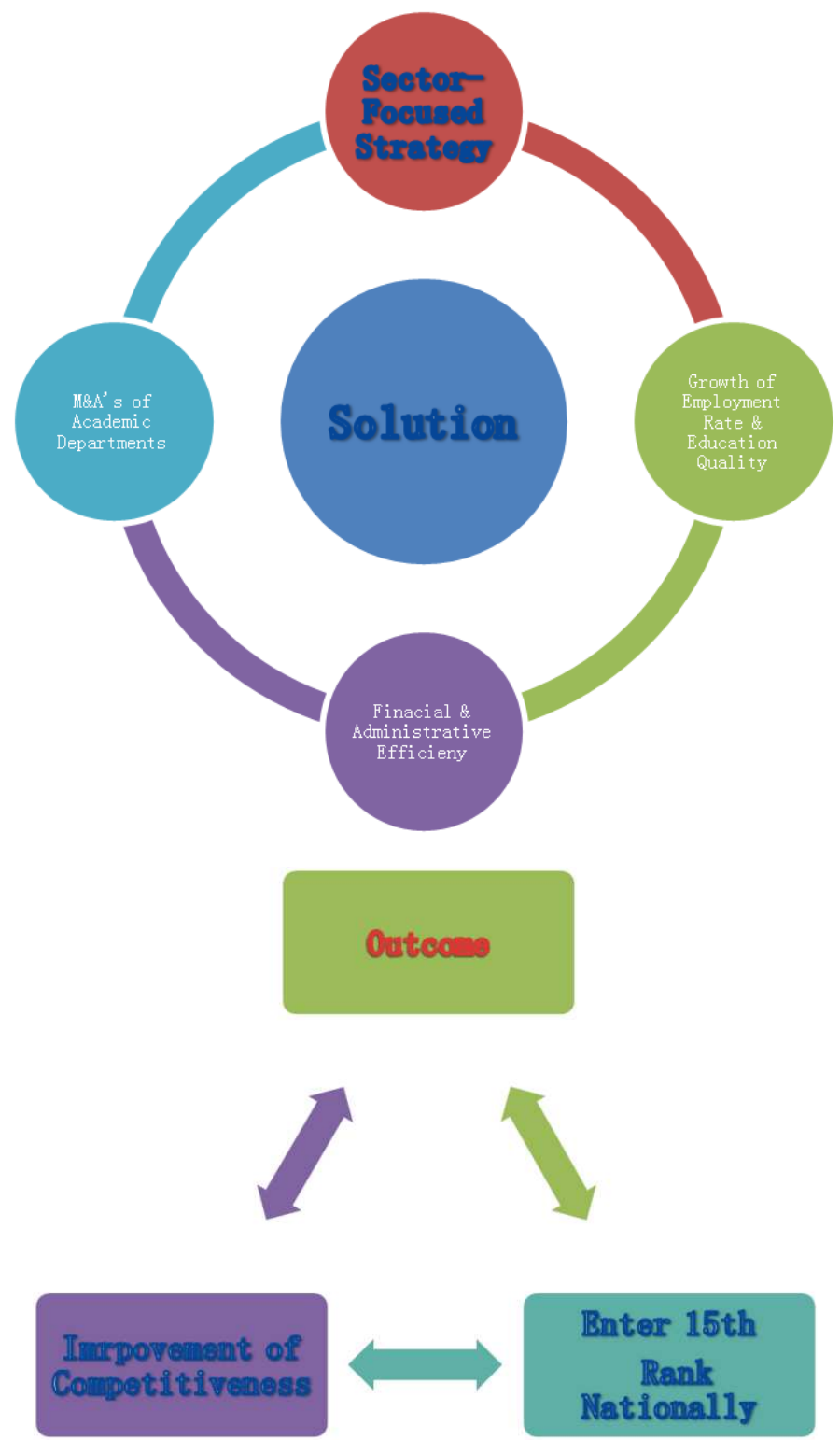

Figure 3. Strategic Goals and Issues of V2020 


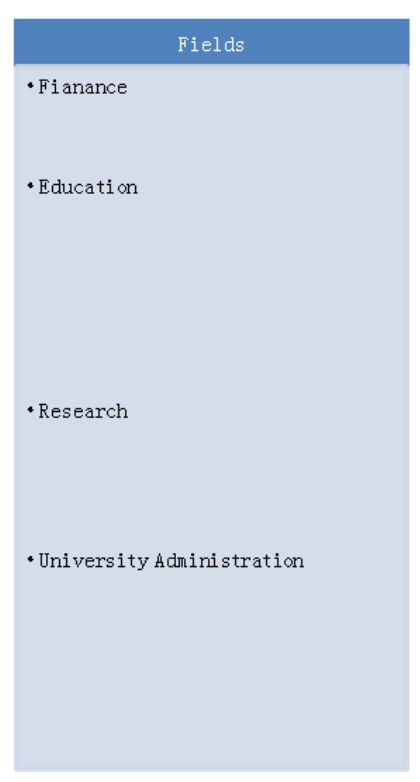

Strategic Goals \& Issues
- Conservative Paradigm of
Expendi ture
- Profit \& Business Concept for
Financial Capbailities
- Mr.A's of Academic Department
- Inter Depratmental Competi tion
- Quali ty Liberal \& Professional
Education
- Linked Concept Between
Undergraduate and Graduate
Education
- Foreign Professors/International
Exchange Programs/On-Line
Education
- Sectorization Growth Strategy
- Inustry Netowork
- Strengthening Incentive System
- Track Sys tem
- Independence of financial
Accountability on Dep. \& Units
- Consumer-Specific Service
- Administartive Education

Responsible Units
- Strategic Plarning Bureua/Hunan
Resources Depratemet/Butsar \&
Budget Branch/Ficilities
Management
- Business and Profit Project
- Strategic Plarning Bureau
- Assessment and Evaluation Force
- Academic Operation Unit
- Facul ty Learning Aids

- Human Resopurces Departemt
- Research Support Brnach
- Strategic Panning Bureau
- Hursar \& Budegt Branch Resources Department

\section{VISION OF CU 2020 (V2020)}

\section{HARMONY\&COLLEGIALITY/INNOVATION/ HAPPIEST UNIVERSITY}

- Ranked 15th Overall Nationally 2020

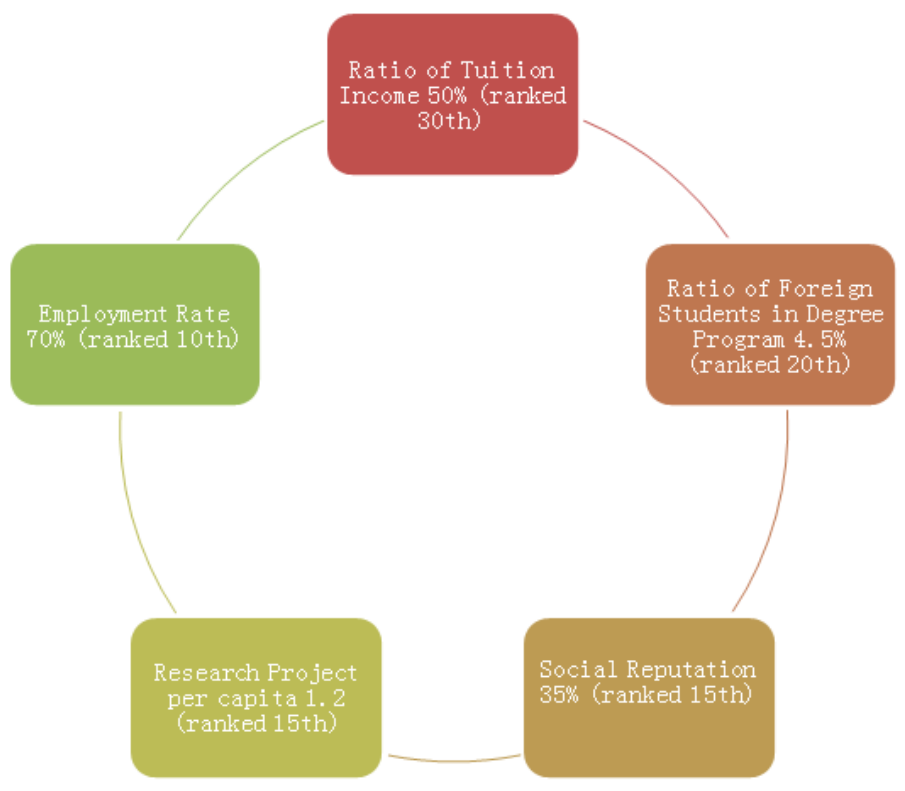

Figure 4. Vision of Chosun University 2020 
CU Will Increase the Competitiveness as

a Regional Core By Way of Annual

Assessment of Departmental Competence.

\section{CU Will Readily Respond to the Change \\ Demand of Environment By Way of M\&A, \\ Management Rationalization \& Innovation \\ and Quota Adjustment \& New Departments}

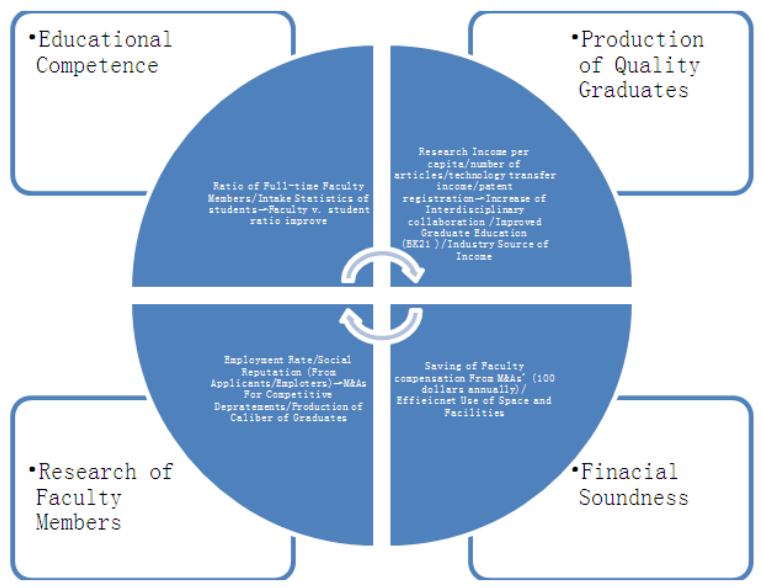

Figure 5. The Vision V2020 and the Place CU Will Reach

\section{Reflections}

On the stories from our neighborhood, we can know several points of nature about the strategic studies or strategies in themselves. First, the strategy actually is present in every context of biological and organizational lives. For example, old men's humble meditation of whether to pursue on-line studies or not may be a simple case involving an individual. This is not to say that $\mathrm{CU}$ Chancellor is old, yet self-assessed intensely and swayed about the launch of V2020. This case can be properly considered more imploring and inextricable given the obvious challenges. However, we can know that there would be present one time to mediate and embrace the plan amid his campus election and to decide an initiation of strategic planning process with the responsible strategic team (Burke, W.W., 2010). We also have a plenty of national institutions named with the words of diplomacy and strategy, which are devoted to the study of foreign affairs. The Green Peace group may have to develop the strategic plans in the process of expanding the network or alliance. Chomsky or Zizek, who had long been concerned with the same area of research interests but allegedly share less agreements or understanding, may exploit their time of preparation for their conference in ways how to strategically facilitate a mutual comprehension about the grey areas of their proposition or theoretical holdings. They also consider the ways for any more extent of sharing or findings of common ground, and possibly some mutual vindication about their intellectual posture. I also consider it should be strategic if divergent each other in the linguistics, national or social background as well as the distinctive tradition between the continental Europe and America in practicing a discourse of philosophy.

So I consider it would not be incorrect if we say the contemporary human beings "homo sapience or animal of strategy." Now almost all cases of various organizations practice a strategic planning process from just one page of mission statement through a scope of details in coverage of the mission, future vision, goals and issues, strategies and implementation as well as monitoring or evaluation system, and so. Given the challenges are more threatening, the need of strategic planning process correspondingly escalates as we review in V2020. Aristotle classed the intrinsic of human beings as "political animal." Some commentators highlighted an economic agility of human beings, hence "economic animal," never solely for the Japanese. Other context was concentrated on the use of tools that the humans are unique among the biological objects on earth. Hence we can say the "homo sapience of tools." In this line, we have the nicknames, such as "homo sapience of using fire" or "homo sapience of walking straight on the 
backbone."

The concept of strategy would be from the ancient times, but its salient feature or universalization, at least its frequency inside our mind, should be seen typical in the primacy and stalemate of liberal individualism or dominance of neo-liberalism (Bryson, J.M., 2011). I also might be proper to class it at the mid level between the "homo sapience and animalistic" since it is neither simplistic nor easy framed unlike the politics or economics. It is animalistic on one hand since it persists, strategically worded, and in the most, has a prime objective to outrival other competitors and survive their person or organization. It is connected with the survival of organization avoiding entropy or death of equilibrium. It is pivotal to vibrate the organizational lives, and touches directly on most of "direct, palpable, practically feasible, enforceable, achievable" in ways of "multiple, interactive, mosaic, procedural and progressive, networked dynamism." Within the disciplines of strategic planning, either a framed concept or ontological discourse in any absolute assumption or indoctrination often retreats, rather, some practical and competing realism would more saliently be exploited (2011). Hence, I consider that this discipline tends to forefront at the upheaval of contemporary glocalized community and to be most widely workable than any other branch of science. The impression is that it is a kind of Avant Garde or post-modern exertion of humans and amorphous or ephemeral as indefinite depending on the circumstances by which each man and organizations are surrounded. This context of dynamism can well flavor in V2020 now pursued by CU.

It would be of human nature since it creates, in the end purpose, the public value and approaches the strategic planning process in ways of science, data, analysis, and steps of exploration to the final documentary form. The formulation and adoption of plan also shows this dual aspect, for example, if we learn "Remember that logical incrementalism can be very effective, but sometimes a big win is the way to go." (2011). A big win could improve the plan as in the final adjudicatory role of CEOs from various competing ideas, which may be animalistic, yet would be humanistic with attempts and logical incrementalism. This context has some niche of interchange between the strategic planning team or stakeholders and CU leadership. As the Faculty Board is powerful in the political geometry, the official line of authority can highly fall in conflict and dissention with the Faculty Board. This has been true during the initial year of 2013, and perhaps can recur in the future if at a slim chance. Logics and argument are prime tools to communicate and educate for the leadership, and vice versa for the aggrieved professors and lecturers. Their disagreement or protest would be a critical point that we share to concern. On the other, grand compromise or big concession is ultimately necessary to support the progress of V2020. This is the only way to reach a big win, and likely an essential prerequisite to produce the public value (2011). This implies that strategic planning process also is of human and diplomatic nature.

The next point of my meditation about the strategies and public policy is that it is destined to be specific often centering on the organization other than abstract audience or vague addressee of theory or philosophy. Therefore, the general strategies will fail if the specific step to implement is absent (2011). This context may be encountered in the above of V2020. It may come in trial and error, pilot testing or sustained exploration, and could be matched with the perception of Franklin Roosevelt. The strategists may explore and do testing if the complete or best ideal form of plan is hard to achieve (2011). However, they may pursue an "as is plan" under the concession of grand plan, often a more comprehensive and idealistic picture of end outcome. That perhaps can be analogous to the status of two scholars who can share the ideals, but diverge on the specifics. I also consider the possible dissention between the Faculty Board and CU leadership in that viewpoint. They actually are lovers of CU, but just disagree on the specifics or action plans. The power struggle of both groups should have to find the points of compromise and the strategic change cycle of V2020 has to be orbited onto the continued track of organizational performance. It would be stupid to set back from a controversy, mere argument for better plan or deference, which may contribute to miss a timely response.

\section{References}

[1] Aguilar, O. (2003). How strategic performance management is helping companies create business value. Strategic Finance, 84(7), 44-49.

[2] Bolon, D. S. (2005). Comparing mission statement content in for-profit and not-for-profit hospitals: Does mission really matter? Hospital Topics, 83(4), 2-9.

[3] Bryson, J.M. (2011). Strategic Planning for Public and Nonprofit Organizations, San Francisco, CA: Josey-Bass.

[4] Burke, W.W. (2010). Organizational Change: Theory and Practice, Sage. Washington D.C.

[5] Dewhurst, S., \& FitzPatrick, L. (2005). Turning stakeholders into advocates. Strategic Communication Management, 9(6), 6-7.

[6] Fogg, C.D (2012).Team-Based Strategic Planning: A Complete Guide to Structuring, Facilitating, and Implementing the Process. Wakfield, RI: CreateSpace Independent Publishing Platform.

[7] Free Management Library (2013a): All About the Strategic Planning, Retrieved from http://208.42.83.77/plan_dec/str_plan/strgzng.htm.

[8] Free Management Library (2013b): Basic Overview of Various Strategic Planning Models, Retrieved from http://managementhelp.org/strategicplanning/models.htm

[9] Free Management Library (2013c): Basics of Identifying Strategic Issues and Goals (2013), Retrieved from http://208.42.83.77/plan_dec/str_plan/strgzng.htm. 
[10] Gousseau, K. (2008). Seniors key concern in strategic planning: Stakeholder meeting in city Thursday. Alaska Highway News, A.1.

[11] Hickman, G.R. (2010), Leading Organizations: Perspectives For A New Era, Sage. Washington D.C.

[12] Kaufman, R. et al (2003). Strategic Planning For Success: Aligning People, Performance, and Payoffs. San Francisco. CA: Josey-Bass.

[13] Kotlin, A. D. (2008). What does it take to have a successful strategic plan?! CPA Practice Management Forum, 4(1), $20-21$.

[14] Laureate Education, Inc. (2013a). Strategic Planning: Collaboration, Cooperation, and Coordination "Approaches to Strategic Planning" with Dr. Paul C. Nutt (approximately 10 minutes).

[15] Laureate Education Inc. (2013b). Strategic Planning: Collaboration, Cooperation, and Coordination "Assessing the Environment" with Dr. Paul C. Nutt (approximately 24 minutes).

[16] Lee, S. F., Lo, K. K., Leung, R. F., \& Ko, A. S. O. (2000). Strategy formulation framework for vocational education: Integrating SWOT analysis, balanced scorecard, QFD methodology and MBNQA education criteria. Managerial Auditing Journal, 15(8), 407-423.

[17] McVea, J. F., \& Freeman, R. E. (2005). A names-and-faces approach to stakeholder management: How focusing on stakeholders as individuals can bring ethics and entrepreneurial strategy together. Journal of Management Inquiry, 14(1), 57-69.

[18] Millett, S. M. (2006). Futuring and visioning: Complementary approaches to strategic decision making. Strategy \& Leadership, 34(3), 43-50.

[19] Parent, M. M., \& Deephouse, D. L. (2007). A case study of stakeholder identification and prioritization by managers. Journal of Business Ethics, 75(1), 1-23.

[20] Roth, B. N., \& Washburn, S. A. (1999). Developing strategy. Journal of Management Consulting, 10(3), 50-54.

[21] Rothaemel, F. (2012). Strategic Management: Concepts, New York, NY: McGraw-Hill.

[22] Sherman, H., Rowley, D. J., \& Armandi, B. R. (2007). Developing a strategic profile: The pre-planning phase of strategic management. Business Strategy Series, 8(3), 162171.

[23] Strategic Plan for the Department of Auditor-Controller of the County of Los Angeles (2013), Retrieved from http://file.lacounty.gov/Auditor/portal/cms1_000664.pdf

[24] Zollo, M., Reuer, J. J., \& Singh, H. (2002). Interorganizational routines and performance in strategic alliances. Organization Science, 13(6), 701-713. 